\title{
アーク放電における発光色制御法について
}

\author{
専阿会員青野 正明* 久保寔** 専䢹会員 板谷 良占平**
}

\section{On Luminous Color Control Methods in Arc Discharge}

\author{
Masaharu Aono (Fellow Member) \\ (Department of Electrical Engineering, Faculty of Engineering, Ehime University) \\ Makoto Kubo Ryohei Itatani (Fellow Member) \\ (Department of Electronics Engineering, Faculty of Engineering, Kyoto University)
}

\begin{abstract}
This paper treats luminous color control methods in pulsed arc discharges of $\mathrm{Ne}-\mathrm{Hg}$ lamps. Luminous color is widely controlled from red color of $\mathrm{Ne}$ to blue color of $\mathrm{Hg}$ by changing the waveform of discharge current. Synthesized waveforms are favorable to make the glow to arc transition sure and to get good performance of color change of the high luminance positive column.
\end{abstract}

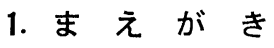

筆者達は, さきに放電管の発光色の電子的制御法としてパルス 方式を提案し，同時に $\mathrm{Ne}-\mathrm{Hg}$ 放電管をグロー放電させ，その陽 光柱の発光色を $\mathrm{Ne}$ の赤色から $\mathrm{Hg}$ の青色まで, 広範囲に連続的 に变色した実験結果を発表した1). 今回，たまたま，水銀極に陰 極輝点が生じて, グロー放電からアーク放電に移行する例を発見 し, この場合でもグロー放電と同様に, 発光色を電子的に制御し らることを確認した.

アーク放電のほらが，グロー放電より当然のことながら放電電 流が大きく, 高輝度が得られるので, 従来の可変色放電の欠点を 克服できるものと期待される.

発光色の制御はパルス方式によっているので, 放電の繰り返し 周波数は $50 \mathrm{~Hz}$ ないし $400 \mathrm{~Hz}$ であり, 各放電のたびに確実にグ ロー放電からアーク放電への移行を起こさせるには, 電極構造だ けでなく印加電圧波形にも工夫を必要とする，ここではアーク放 電をさせるに適した印加電任波形に対する発光特性についての実 験結果について述べグロー放電とアーク放電の発光特性の違い について報告する，さらに，アーク放電に拈いてはグロー放電の 場合より実効的陽光柱が長くなるといら利点をもっている。

\section{2. 変色の原理}

パルス方式による変色法は, 立ち上がりの急しゅんなパルスで
放電させるとき, 放電開始直後の非平衡状態時に, 過渡的に平衡 状態時より高い電子温度が得られる現象を利用するものである. 電子温度を制御するには次のような方法が考えられる。

(1) パルス幅変化法 ${ }^{1)}$

(2) 電圧変化法 ${ }^{1)}$

(3) 周波数变化法 ${ }^{1)}$

(4) 直流電流重畳法 ${ }^{2}$

(5) 放電電流波形変化法 ${ }^{3)}$

以下に,これらの制御法の変出原理のあらましについて述べる。 (1) パルス幅変化法

$\mathrm{Ne}$ と $\mathrm{Hg}$ の発光強度をとれぞれ $I_{N e}$ (赤), $I_{H g}$ (青)とすると, パルス幅が狭いときは, 放電期間中に高電子温度の非平衡期間の 占める割合が大きいから， $I_{N e} / I_{I I g}$ が大となって赤色に発光す る. パルス幅が広いときは, 非平衡期間に対して低電子温度の平 衡期間の割合の浪らが大きくなるため, $I_{N e} / I_{H g}$ が小となって青 色澄光する.

(2) 電圧 変化法

印加電圧を高くすると， $I_{N e}$ と $I_{H g}$ がともに増加するが， $I_{N e}$ の增加率のほらが $I_{H g}$ のそれより大きいため， $I_{N e} / I_{H g}$ が大とな って赤色が強くなる.

(3) 周波数変化法

パルスの繰り返し周波数を高くすると, 前パルスからの残留イ オンの影響が大きくなって, 放電開始直後の非平衡の程度が弱ま り, この間の電子温度が低下して $I_{N e}$ が減少し赤色が弱くなる.

(4) 直流電流重畳法

パルス放電に直流放電を重盢すると，パルス放電直前の荷電粒 
子が，周波数変化法による残留イオンと同様な効果を持つので， パルス放電期間の変色が可能である。直流放電期間は $\mathrm{Hg}$ だけが 発光するため, 全期間の平均の発光色はパルス放電期間だけのも のより青色が強い。

\section{(5) 電流波形変化法}

放電電流の立ち上がりが早い注ど，すなわち $d i / d t$ が大きいほ ど $I_{N e}$ が増大することを利用するもので， $d i / d t$ を変えることに より変色を行なう.

陽光柱の特性は，アーク放電に打いてもグロ一放電の場合と同 様であるから変色の原理は全く同じである．ただ，陰極の電子放 出機構が異なり，パルス放電にあっては各パルスごとに，グロー からアークへの移行を確実に行なわせなければならない。このた めに電極構造はもちろんのこと，制御回路にもそれに適したもの を見出す必要がある.

\section{3. 実 験 方 法}

変色の央験はパルス幅，印加電圧，繰り返し周波数および放電 電流波形を変えて行なった．使用した放電管，パルス電源および 測光装置は次のと拈りである.

\section{1 放 電 管}

アーク放電を発生しやすい陰極構造を見出すために，数種類の 電極を試作して検討した結果，図 1 のように，Ni 板の後方に $5 \phi$ のガラス管を約 $1 \mathrm{~mm}$ の間隔で配置し，この間隙に $\mathrm{Hg}$ を満 たす構造のものが成績が良かった．陽極は陰極と同様の $20 \phi$ の $\mathrm{Ni}$ 板を，陰極より $15 \mathrm{~cm}$ の位置に対向させた．放電管内には $\mathrm{Ne}$ を 10 Torr と Hg を多い目に封入してある。

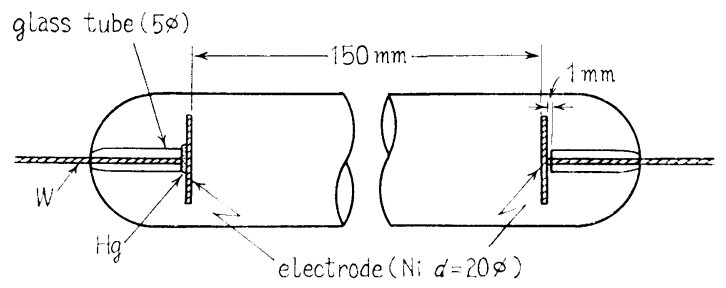

図 1 陚作放電管

\section{2 パルス電源}

出力波形として, 矩形波, 三角波, 矩形と三角の合成波拉よび 階段波が得られる。矩形波は幅と高さを，三角波は幅と傾きを， 階段波は各段の幅と高さをそれぞれ任意に変えることができる.

アーク放電に拄いては, 大きな電流が流れるから電源の保護の ため, 印加電圧を最高 $1,000 \mathrm{~V}$ をで, 周波数を $50 \mathrm{~Hz}$ から $400 \mathrm{~Hz}$ まで，パルス幅を矩形パルスのときは $25 \mu \mathrm{S}$ を，合成波拈よび

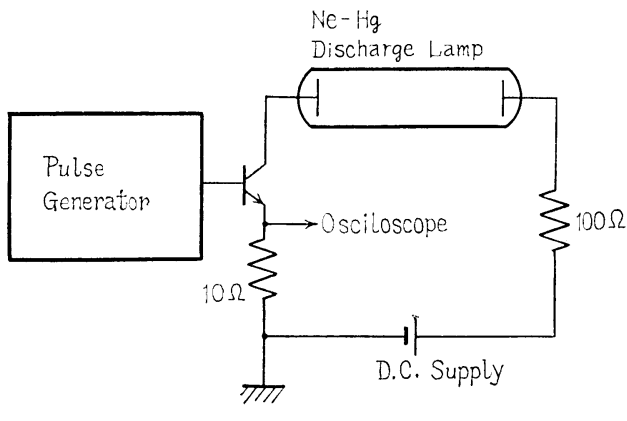

図 2 点灯回路

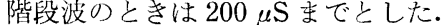

さらに過電流防止用として，図 2 の点灯回路に示すように， 電流波形測定用の抵抗 $10 \Omega$ 以外に, $100 \Omega$ の抵抗を放電管に直列 に挿人した.

\section{3 測 光 装 置}

分光分布と，スペクトルの時間変化測定のための測光装置を 図 3 に示す，受光部には長波長側にも高感度を有するフォトマ ル（EMI 9558 B）を使用し，分光分布の測定には負荷抵抗として $10 \mathrm{k} \Omega$ を接続して高出力を得て，応答速度が問題となる時間变化 の測定には $25 \Omega$ を接続した。フォトマルの出力をボックスカー 積分器 (BX-530A, NF 製) によって, 平均化と堌幅の操作を行 なってペンレューダで記録した．放電のデューティ比が小さいた め分光分布の測定にもボックスカー積分器を使用し, ゲート幅は フォトマルの出力波形の幅に合わせた。

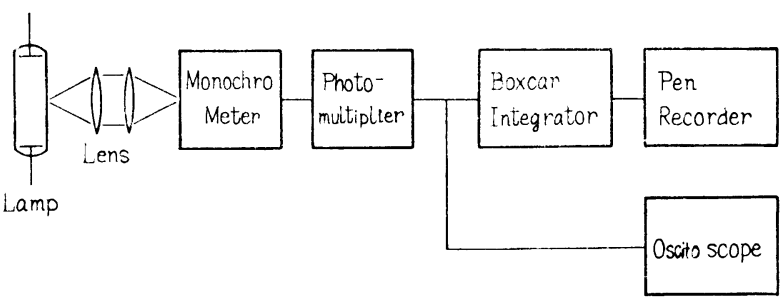

图 3 测䇥采

ボックスカー積分器の特性上, $0.5 \mu \mathrm{S}$ 以下のゲート愊が得ら れないので，時間変化の大きなスペクトルの過渡特性の測定には フォトマルの時間分解測光方式 ング時間を $50 \mathrm{nS}$ とした.

\section{4. 実験結果および検討}

\section{1 矩形波パルスによる実験結果}

低電圧に扣いても，陰極の状態と放電回路の条件によってはグ ロー放電からアーク放電に移行することがある。

グロー放電かアーク放電かは, 放電管端子電圧と陰極輝点の観

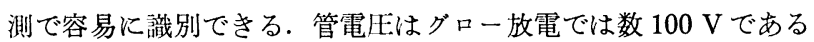
が，アーク放電になると $100 \mathrm{~V}$ 程度にまで低下する。

矩形波パルスを印加したときのグロー放電と, アーク放電の放 電電流を比較するために, 印加電圧 $700 \mathrm{~V}$, 繰り返し 周波数 50 $\mathrm{Hz}$ のグロー放電と，アーク放電の電流波形を 図 4 に示す. (a) がグロ一放電のもので，パルス印加より最大電流に達するまでを

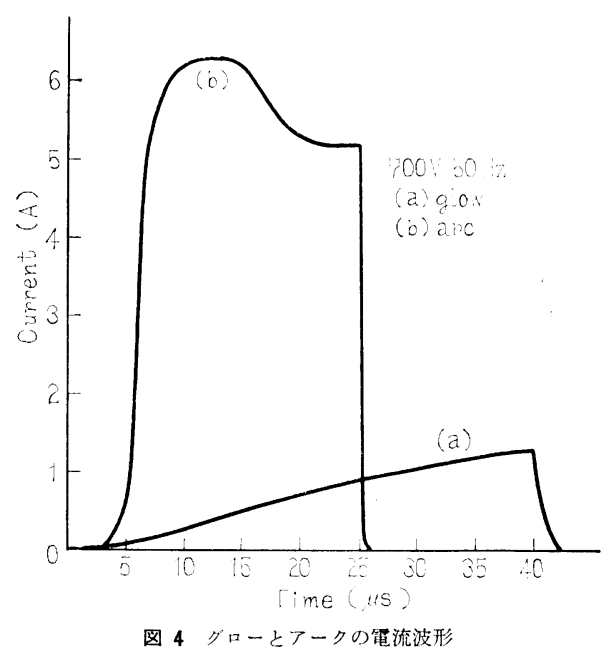


示し，(b)はグロ-放電から陰極輝点が発生して，アーク放電に移 行したときの電流波形で岁り，電源の容量の例約からバルス幅を $25 \mu \mathrm{S}$ とした。 また，放電回路の抵抗はグロ一放電のときは $10 \Omega$

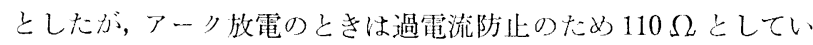
る.

放電電流は，グロ一放電のとき放電開始よりゆるやかに上昇し て約 $40 \mu \mathrm{S}$ 後に最大值 $1.27 \mathrm{~A}$ に達し，パルス幅をこれ以上に広 くするとゆるやかに減少して一定值に落ち着く。(b)においては, 放電開始直後はグロー放電であるが約 $3 \mu \mathrm{S}$ 後にアーク放電に移 行し, アーク放電に移行後の電流の立ち上がりは非常に早く, 放 電開始より約 $10 \mu \mathrm{S}$ 後に最大值 $6.3 \mathrm{~A}$ に達する. 約 $14 \mu \mathrm{S}$ までは ほぼ一定電流を保つがそれ以後減少し始め, 約 $20 \mu \mathrm{S}$ 後に定常電 流 $(5.2 \mathrm{~A})$ 飞落ち着く.グロー放電からアーク放電への移行時 点は絶えず変動していて, 電圧と周波数が低いととの変動幅は数 $10 \mu \mathrm{S}$ にもなることがあるが，印加電压と周波数を高くしたとき は変動幅を $1 \mu \mathrm{S}$ 程度に狄くすることができる.

放電管の発光状態を钼察すると，グロ一放電の場合は憕色に強 く発光している負グローとファラデー瞕部があるために, 変色可 能な陽光柱の長さが陰極側で $1.5 \mathrm{~cm}$ 程度短縮される. アーク放 電のときは微小な陰極輝点が白色に輝き, 輝点より直径約 $3 \mathrm{~mm}$ の球内に $\mathrm{Hg}$ の青色光が見られるが，それ以遠では陽光柱を形成 している. したがって, アーク放電の場合はグロー放電の場合よ り実効的陽光柱が長くなって, 変色可能な面積が桩大される.

印加電圧を $700 \mathrm{~V}$ ，パル久幅を $5 \mu \mathrm{S}$ ，周波数を $50 \mathrm{~Hz}$ としたと

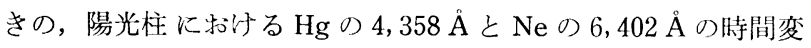
化を図 5 に示与.

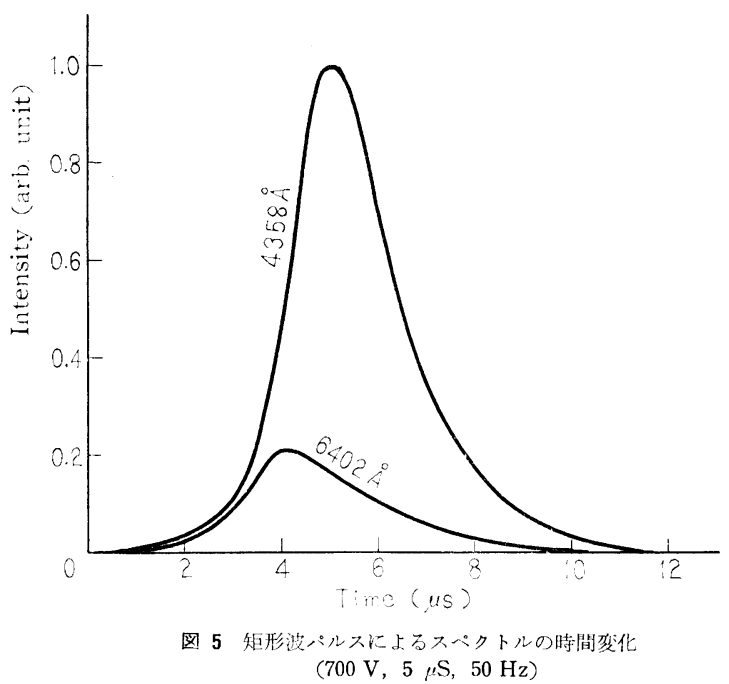

電流の立ち上がりと同様に，スペクトルの立ち上がりもアーク 放電のときの汪うがグロー放電のときより早い。また，グロー放 電のときと同様に, $\mathrm{Ne}$ の立ち上がりのほらが $\mathrm{Hg}$ のそれより早 い(文献(1)図 7 参照).

$\mathrm{Ne}$ のスペクトルは，電流がな打上昇しているにもかかわらず， 放電開始後約 $4 \mu \mathrm{S}$ で最大に達し減衰を始める. $\mathrm{Hg}$ のスペクトル は立ち上がりが遅いため， $5 \mu \mathrm{S}$ のパルス幅ではまだ最大に達せ ず，電流が切れると同時に減衰を始める.

アーク放電とグロー放電の分光分布を 図 6 亿示す.ただし, 印加電圧と周波数は，いずれの場合もそれぞれ $700 \mathrm{~V}$ と $50 \mathrm{~Hz}$ で

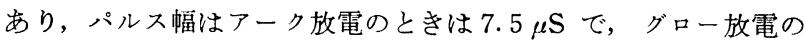

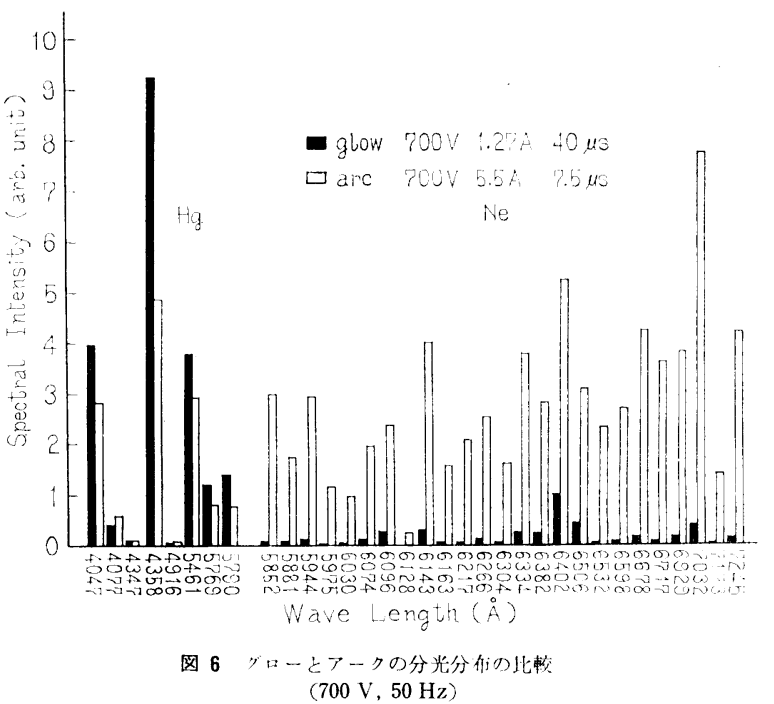

ときは40 $\mu \mathrm{S}$ である.

$\mathrm{Ne}$ のスペクトルはいずれの場合も，これらパルス幅内で最大 に達して急速に減衰してしまらから（四 5 扎よび文献(1)の四7 参 照), この程度にパルス幅が異なっても, アーク放電とグロ一放 電の $\mathrm{Ne}$ 線の強度を比較することには意味がある.

アーク放電とグロー放電のスペクトルの強度比 $I_{a} / I_{g}$ は, 6,402 Åでは5.2となり，7,032 Åでは 17.1 となっていずれもアーク放 電のときの汪うがはるかに強い。これは電流の上昇率がアーク放 電のときのほうが，グロ一放電のときより大きい(約43倍) ため と考えられる．また， $I_{a} / I_{g}$ の值は各スペクトルで異なる。

このことから, 赩の発光色はアーク放電に拈いて容易に得ら れることがわかる.

$\mathrm{Hg}$ のスペクトルは最大に達して以後減衰するが，放電期間中 発光を維持するため, パルス幅を広くすれば強度が増す。

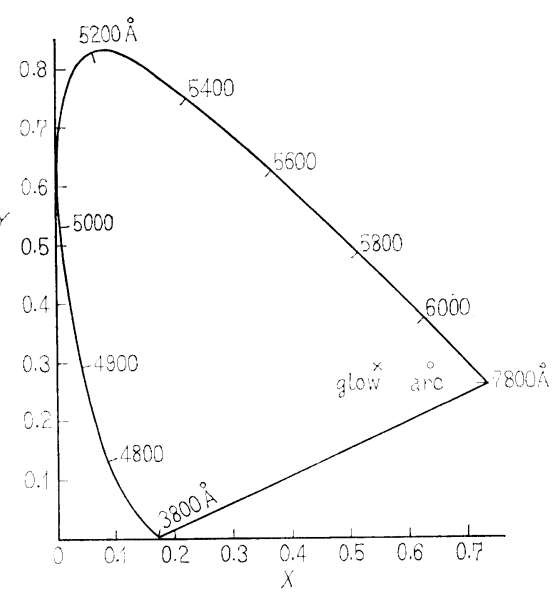

図 7 フークとグローの色度の比湿

印加電圧 $1,000 \mathrm{~V}$, パルス幅 $6 \mu \mathrm{S}$, 周波数 $50 \mathrm{~Hz}$ のグロ一放電 の色度（文献(1)の図 4 参照）と，印加電任 $700 \mathrm{~V}$ ， パス幅 7.5 $\mu \mathrm{S}$, 周波数 $50 \mathrm{~Hz}$ のアーク放電の色度（図6のアーク放電の分光 分布のもの)をCIE 色度図上に示すと図 7 のようになる. 印加 電圧が低く，パルス幅の広いアーク放電に拈いて純 $\mathrm{Ne}$ の赤色に 近い発光色が得られた.

(1) パルス幅変化による実験結果

印加電压 $700 \mathrm{~V}$ ，周波数 $50 \mathrm{~Hz}$ のときパルス幅を $6.6 \mu \mathrm{S}$ から 


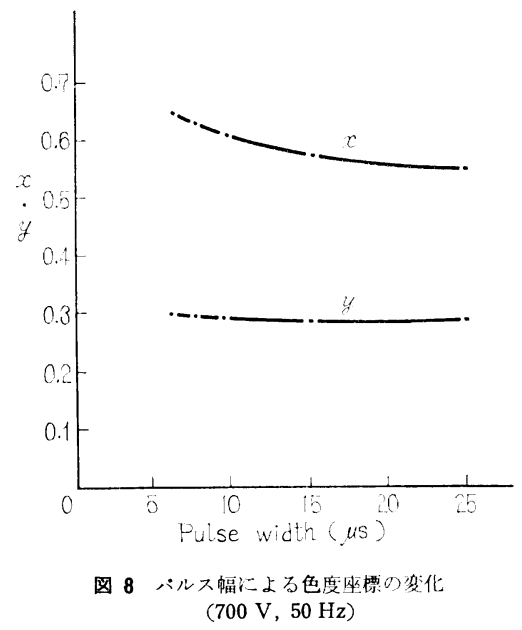

$25 \mu \mathrm{S}$ まで変えて放電させたときの色度の $x, y$ 夾標の変化を 图 8 亿示す.

$6.6 \mu \mathrm{S}$ のときは純 $\mathrm{Ne}$ の赤色に近い発光が得られるが, $25 \mu \mathrm{S}$ ではまだパルス幅が狭いため青色光が得られない。

\section{(2) 印加電圧変化による実験結果}

印加電圧を $500 \mathrm{~V}$ より $800 \mathrm{~V}$ ま変えたときの色度座標の変化 を図 9 に示す.このときのパルス幅の幅を各電圧で放電開始よ り放電電流が最大に達するまでとしたため, 電圧が高くなるにつ れ図に示すよらにパルス幅は狭くなっている，各電圧に対する最 大放電電流も図 9 に合わせ示してある.アーク放電に扣いては低 電圧に拈いても $d i / d t$ が大きいため容易に赤色が得られる.

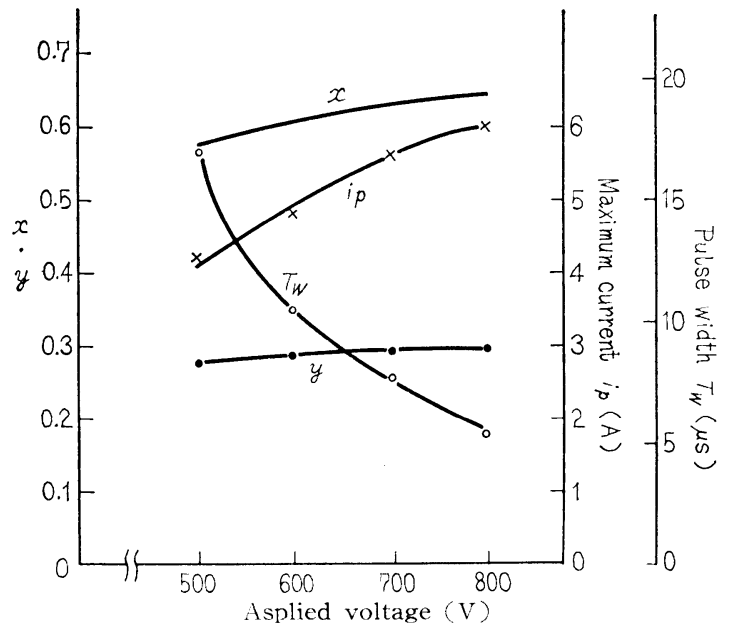

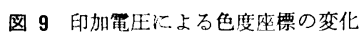

\section{（3）周波数変化による実験結果}

印加電圧を $700 \mathrm{~V}$, 放電電流のピーク值を $5 \mathrm{~A}$ 一定に保って, 周波数を $50 \mathrm{~Hz}$ から $400 \mathrm{~Hz}$ まで変えたときの色度座標を 図 10 に示す．周波数が高くなるにつれアーク放電への移行が早くなる ので, 電流ピークを一定に保つために図に示すようにパルス幅を 各周波数ごとに調節した. 周波数を高くするにつれ $\mathrm{Ne}$ の発光が 弱まり青みを増すことがわかる.

以上の実験結果より，アーク放電に扎いてもグロー放電に打け ると同様に, 矩形パルスの幅, 印加電圧および周波数を変えるこ とにより, 赤色から青色までの広範囲の変色の可能なことが予想 される、しかし，今回の実験は電源容量の制約からパルス幅を十 分広く, また周波数を十分高くできなかったため, 青色の発光を

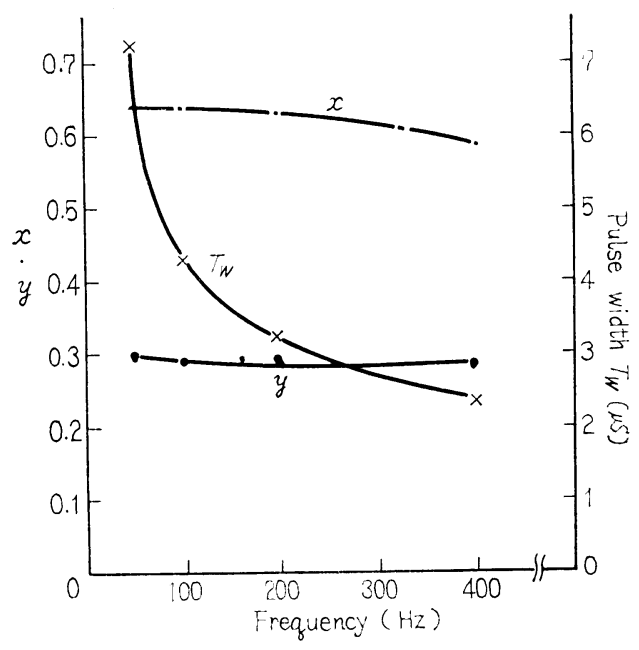

图 10 周波数に上万色度座標の変化 $(700 \mathrm{~V})$

得ることができなかった。

\section{3 合成波パルスによる実験結果}

\section{（1）矩形と三角の合成波による実験結果}

グロー放電においては三角波でパルス点灯し，その傾きを変え ることにより広範囲の変色が可能であった ${ }^{3)}$. しかし，傾きの小 さい三角波で放電させると, グロー放電からアーク放電への移行 が不安定になると同時にグロ一放電期間が長くなる.グロー放電 期間が長くなると陰極が加熱されて，Hg が陰極より蒸発してし まい陰極輝点が発生しなくなる．そこでこの欠点を除去するため 三角波の先端に幅の狭い矩形パルスを配置した合成波によって放 電させた.

三角波のパルス幅を $180 \mu \mathrm{S}$ ，ピーク電流を $0.46 \mathrm{~A}$ として，こ の先端に $7 \mu \mathrm{S}$ の矩形波を配固した合成波で放電させたとさの電 流と 4,358 ̊ および $6,402 \AA$ の時間変化を 図 11 に示す.
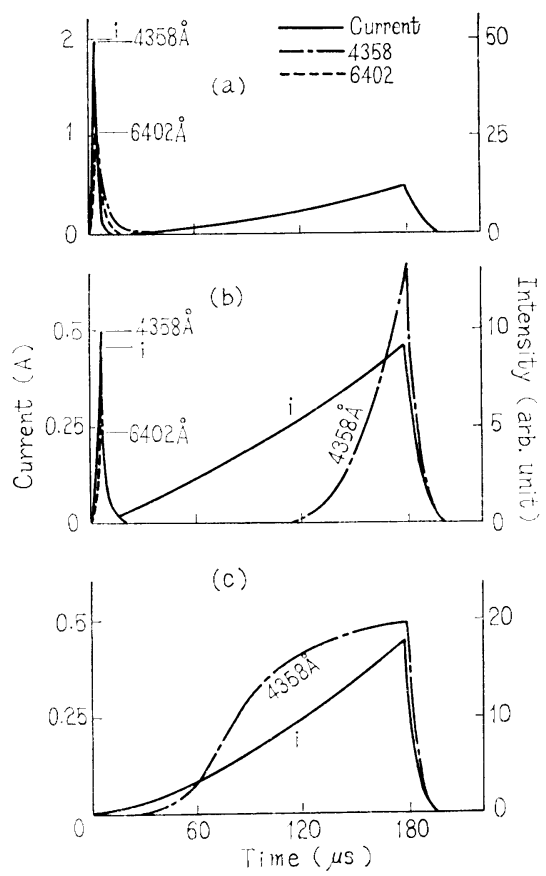

図 11 矩形と三角の合成波による電流と スペクトルの時間变化

(a)は矩形波の高さを $2 \mathrm{~A}$ と高くしたときのもので， $\mathrm{Hg}$ と $\mathrm{Ne}$ のスペクトルは, いずれも矩形波内だけで強く発光し, 三角波内 
ではほとんどゼロになっている。したがって，このときの三角波 は取り除いても発光には影響しない。

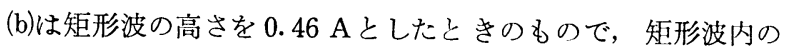
$\mathrm{Hg}$ と $\mathrm{Ne}$ の強度はいずれも $1 / 6$ 程度に低下する. $\mathrm{Hg}$ のスペクト ルは三角波の後半に拈いて再び現われ, 電流の増加とともに強度 を増すが， Neのスペクトルは三角波内では発生しない。

(c)は矩形波を取り去って三角波だけとしたときのものである. $\mathrm{Ne}$ のスペクトルは, アーク放電に移行值後にわずかに現われる 以外は放電期間中現われない. $\mathrm{Hg}$ のスペクトルは電流の増加と ともに強度を增していくが，しだいに飽和の傾向を示す。

(a)の三角波内で $\mathrm{Ne}$ も $\mathrm{Hg}$ も発光しないのは, 矩形波内で生成 されるイオン量が多いので, 次の三角波内において残留イオン密 度が高く, 放電を維持するのに高電界を必要としないから, 電子 温度が上䄯しないためと考えられる.

(b)のように矩形パルスが小さいときは，矩形波内で生成される イオン量が(a)の場合ほど多くないため, 三角波の途中で残留イオ ンが消隇してしまうと, 高電界となって電子温度が高まり, 再び $\mathrm{Hg}$ が発光を始めるものと考兄られる.

矩形と三角の合成波による色度変化を 図 12 に示す。

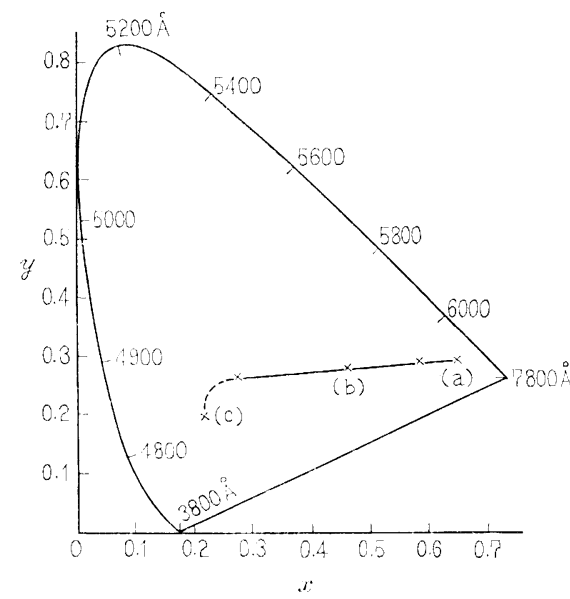

图 12 矩形と三任の合成波による色度変化

図中の(a)，(b)，(c)はそれぞれ図11の(a)，(b)，(c)の放電電流波形 のときの色度を示す。

(a)はパルス幅の狭い矩形波によるものと同様の発光特性を有す るから Ne の強度が強く赤色である. (b)は矩形波内の $\mathrm{Hg}$ と $\mathrm{Ne}$ の 発光はともに弱くなるが， $\mathrm{Hg}$ は三角波の途中から再び現われる ため全体として Ne の割合が減少して青みが強い。(c)は $\mathrm{Ne} の$ 発光がほとんど消隇し， $\mathrm{Hg}$ の発光は(b)よりさらに強くなるため 青色である．この方法では三角波を一定として矩形波の高さを変 えるだけで広範囲の変色が可能であった.

困12の(c)が下がっているのは, Ne が発光しないときの水銀の $4,358 \AA$ と $5,461 \AA$ の強度比 $\left(I_{4358} / I_{5461}\right)$ の值が, 発光している ときの值より大きくなるためである.

矩形波でアーク放電に移行しても, 三角波の初期の放電電流が 小さい期間に拈いてグロー放電に逆戻りすることがある．これが 長く繰り返されると陰極が加熱されて $\mathrm{Hg}$ が蒸発してしまい, 陰 極輝点が発生しなくなり, その結果, 矩形波内に打いてもアーク 放電に移行しなくなる.

（2）階段波（矩形の合成波）による実験結果

さきの合成波では，三角波の前に矩形波を配置してアーク放電
への移行点を安定させた。しかし，三角波の初期の電流が小さい 期間に無発光となることがある，そこで，安定にアーク放電に移 行し，かつ無発光の期間もなく，より微細な変色が行なえるよう に，幅の狭い複数個の矩形で合成した階段波を用いて点灯した。 第一段の幅を $4 \mu \mathrm{S}$ ，第二段以後の幅をそれぞれ $15 \mu \mathrm{S}$ とて， 全体のパルス幅が約 $80 \mu \mathrm{S}$ のとき，各段の高さを变えて放電させ た場合の電流とスペクトルの時間变化を図 13 に示す.
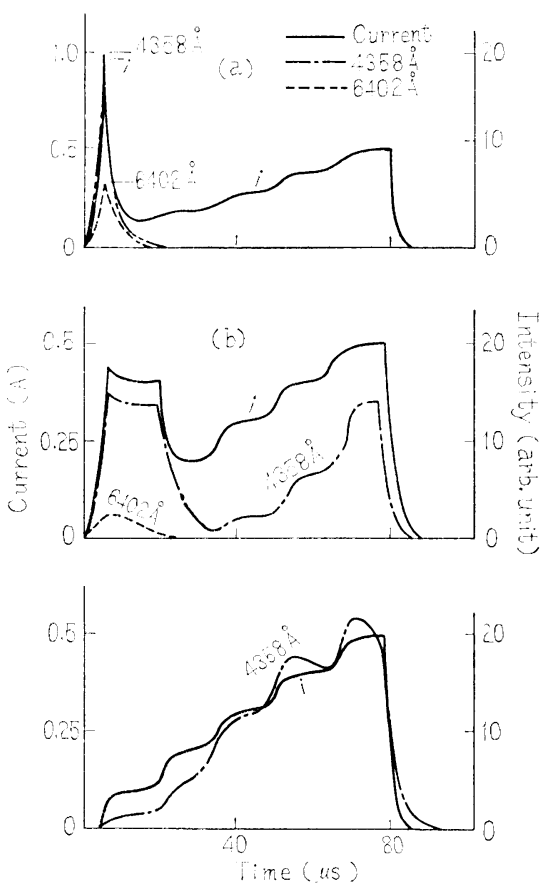

図 13 階段波に上る電流とスペクトルの 時間変化

(a)の電流は第一段が $0.98 \mathrm{~A}$, 第二段 $0.15 \mathrm{~A}$, 第三段 $0.2 \mathrm{~A}$, 以後の各段ではそれぞれ $0.1 \mathrm{~A}$ ずつ増加して, 最終段で $0.5 \mathrm{~A}$ と した. $\mathrm{Hg}$ と $\mathrm{Ne}$ のスペクトルは第一段内だけで強く現われて, 第二段の中途でほとんど消隇してしまう。

(b)の電流は第一段と第二段が $0.4 \mathrm{~A}$ で, 第三段以後は(a)と同じ である. Neのスペクトルは放電開始より約 $7 \mu \mathrm{S}$ 後に最大に達し て二段目終了付近で消隇してしまう．Hg のスペクトルは，電流 がピークに達する（約 $6 \mu \mathrm{S}$ ) のと同時に最大に達し, 電流一定の 間はほぼその強度を維持する．第三段で電流が減少すると強度も 弱くなるが，第四段以後の電流の増加とともに再び強くなる.

このとき， $\mathrm{Hg}$ と $\mathrm{Ne}$ の発光が弱い第三段拈よび第四段の電流 をゼロにすると，次段のパルスで $\mathrm{Hg}$ も $\mathrm{Ne}$ も発光するようにな る、これは周波数を高くしたのと同様な効果である.

(c)の電流は第一段をゼ口とし, 第二段以後は0.1 A ずつ増加し たときのものである.このとき， $\mathrm{Ne}$ のスペクトルは全期間にわ たって現われない，Hgのスペクトルは電流の増加とともに強度 を增すが，電流が大きい段では各段の中途で強度が減少し始め る、また，電流が大きくなるにつれ強度は飽和の傾向を示す。

階段波による色度変化を図 14 に示す. 図中の (a)，(b)，(c)の 各点は，それ艺れ図13(a)，(b)，(c)の電流波形汶対応寸る色度であ る.

階段波の高さだけを変えることによって，パルス幅の狭い矩形 波のときに得られる赤色から， Hg だけの青色まで広範囲の変色 が可能であった．(c)の色度点が下がっているのは図11の場合と同 


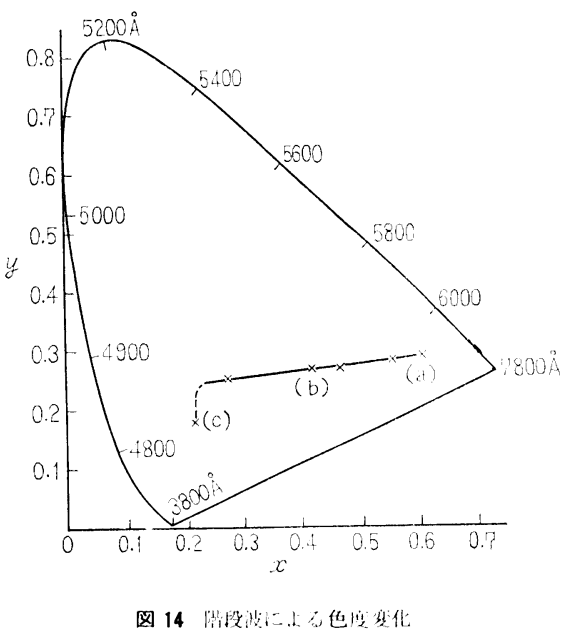

様に Neダ発光しないときは, 発光しているときより $I_{4358} / I_{5461}$ の 值が大きいためである。

\section{4 輝度の測定結果}

$\mathrm{Hg}$ の青色光の輝度はパルス幅を公く，放電電流を大きく，周 波数を高くすれば高めることができるが，Ne はパルス印加直後 の短期間内に执いてだけ発光するから, 赤色光の輝度の向上には 限界がある。

アーク放電とグロー放電において，電流が最大に達するまでの パルス幅としたときの輝度と印加電圧との関係を図 15 に示す. ただし，アーク放電は周波数を $200 \mathrm{~Hz}$ ，放電回路の抵抗を $110 \Omega$ と $10 \Omega$ としたときおよ゙ $50 \mathrm{~Hz}$ で $10 \Omega$ の三と拈りであり， グロー放電は $50 \mathrm{~Hz}$ で $10 \Omega$ のときのものである.

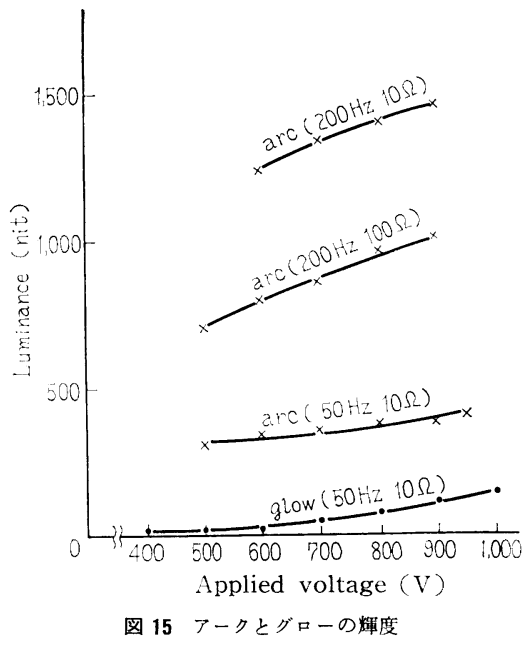

印加電王を上昇するほど輝度が高くなるのがわかる．周波数を 高くするときは，電流の上昇率が大きくなるためパルス幅を狭く した. しかし最大電流の大きさは洼とんど変わらないため輝度は 周波数に比例して高くならない。

回路の抵抗を小さく寸るときも，電流の立ち上がりが早くなる のでパルス幅を狭くした，このときは最大電流が増加するため輝 度が高くなる.

グロー放電の輝度は, 印加電圧, 周波数技よび抵抗が等しいア 一ク放電の輝度の約 $1 / 4$ となる. 両者の発光色は当然のことなが ら異なっている.

図11(a)，(b)，(c)の矩形と三角の合成波の輝度は，それぞれ 180 nt，93 nt，163 nt であり，図 $13(\mathrm{a}) ，(\mathrm{~b}) ，(\mathrm{c})$ の階段波の輝度は， それぞれ $150 \mathrm{nt}, 130 \mathrm{nt}, 140 \mathrm{nt}$ であった.

赤色と青色の輝度はいずれもほ注等しくなったが，中間色の輝 度は，とくに矩形と三角の合成波に怙いて低くなった。これは中 間色のとき, $\mathrm{Hg}$ と $\mathrm{Ne}$ のいずれるが発光しない期間が生じるた めでめる.

\section{5. 考察}

矩形パルス点灯のとき，グロー放電では赤色を出せるパラメー 夕範用が比較的狭かったのに対し、アーク放電では逆に限られた パルス幅では赤色は出しやすい代わりに，青色を出しにくいとい う結果である. しかし青色を出すことは十分可能で，そのために はパルス幅を広くする必要がある，このことは放電管を単独で使 用する場合はあまり問題にならないが，ディスプレイ用に多数の 放電管を用い，しかも掃引点灯する場合には長いパルス幅を必要 とすることは不利である。

これに対し，合成波はパルス幅，電生および周波数を固定し， 波形を変えるだけで变色範囲を広くとれるから，ディスプレイに 応用するとき掃引を規則的に行ならことができ, 掃引制御が簢単 となる利点がある.

さらに階段波の場合には，波形制御をディジタル的に行なえる ため, 将来計算機と結合して色を变えることす可能となり応用範 囲も払張できるものと思われる。

\section{6. む す ひ}

グロー放電において，発光色制御が可能であったパルス方式を アーク放電に対して試みた.

以上の結果を要約すると次のようになる.

(1) $\mathrm{Ne}-\mathrm{Hg}$ 放電管において，パルス放電ごとにグロー放電か らアーク放電への移行が数 $\mu \mathrm{S}$ 以内に起こることが観測された.

(2) アーク放電の電流上昇率は $1.38 \mathrm{~A} / \mu \mathrm{S}$ であり，グロー放 電のそれは $0.032 \mathrm{~A} / \mu \mathrm{S}$ である. この違いによってアーク放電 に拈いては，純粋に近い赤色光が得られる.

（3）アーク放電においては，赤色は矩形波パルスで容易に得ら れるが，青色を得るにはパルス幅をグロー放電のとき以上に広く 変化させることが必要である。

（4）電流波形の立ち上がりを制御して変色する方法では，青色 を得るためのゆるやかな立ち上がりの場合に，グロー放電からア 一ク放電への移行を保証することが必要であって，この目的のた めに矩形波と三角波の合成波拉よび階段波状合成波を試みた。 そ の結果，変色の点では両者共に満足すべき結果を得たが，変色お よび輝度の両方を自由に制御できる点において，またグロ一放電 からアーク放電への移行を確実にする点に批いて, 後者がすぐれ ている.

（5）アーク放電の場合は，グロ一放電に見られる負グローとフ ァラデー暗部がなく，陽光柱は陰極輝点近くまで伸びており，可 変色の有効部分がグロー放電の場合より長い.

(6)アーク放電では電流が大きいため高輝度が得られる. 周波数 $50 \mathrm{~Hz}$ ，パルス幅 $3.5 \mu \mathrm{S}$, ピーク電流 $27 \mathrm{~A}$, 平均電力約 $3 \mathrm{~W}$ の とさ最大輝度 $1,480 \mathrm{nt}$ でグロ一放電の場合の 10 倍以上である.

おわわり，本研究にあたり測光系の分光感度の校正に便宜をは かってくたさった京都大学工学部助教授野口透先生ならびに, 実 験に終始協力いたたいた，愛媛大学工学部技官黒河久悦氏に感謝 
の意を表する次第である。
参 考 文 献
(1) 青野, 久保, 板谷: 照学誌 60-10（昭51） 529 536
(2) 青野, 久保, 板谷: 昭52 四国支部連大予稿集 163,164

（3）竜子ほか：電気学会光源関連装置研 究会資料 LS-78-3 （昭53）

(4) 南, 内田：応物 38-8（昭44）789 796

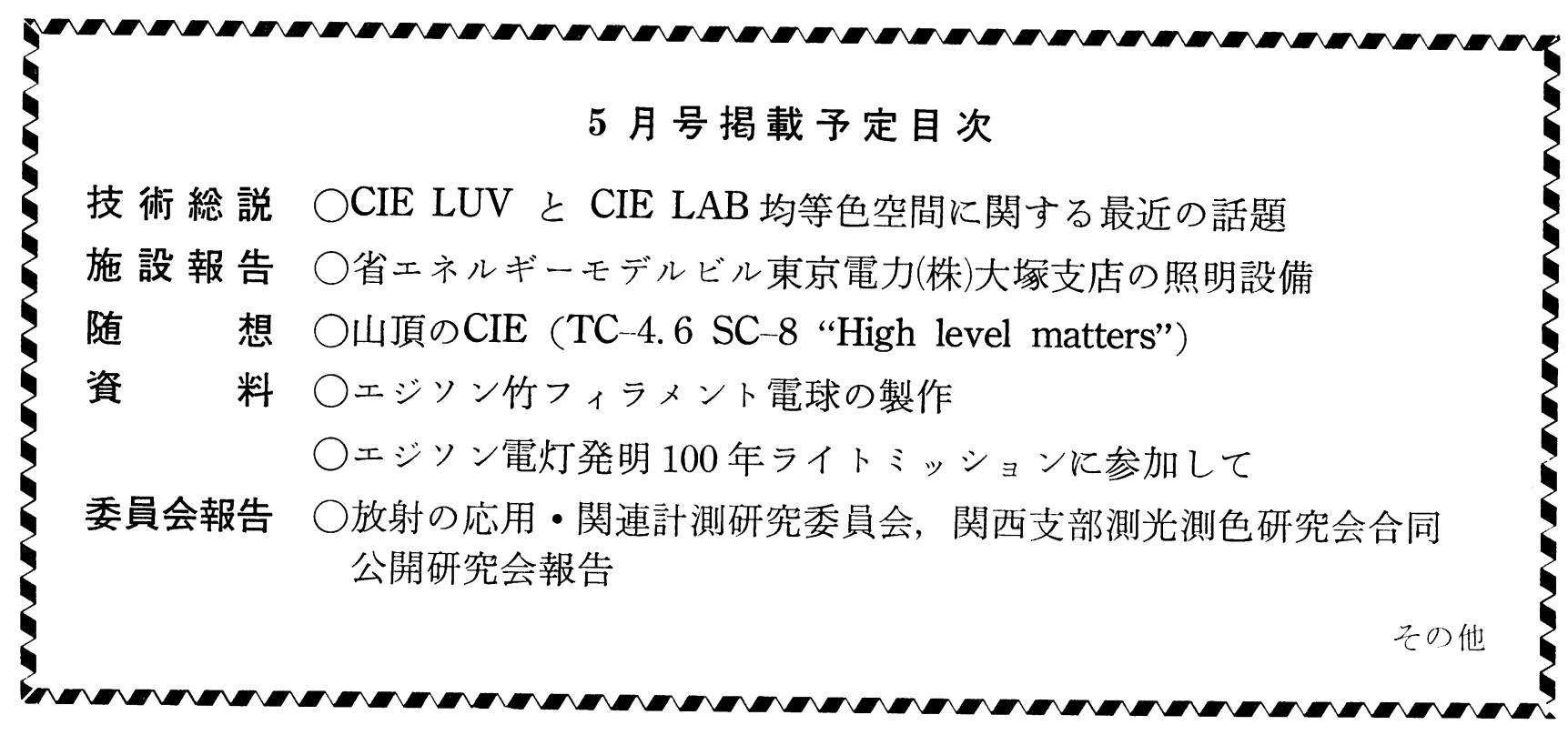

